\title{
CONTENT ANALYSIS ON THE ENGLISH TEXTBOOK ENTITLED \\ BAHASA INGGRIS SMA/MA KELAS X
}

\author{
Ari Sihad Syale \\ English Language Education Department \\ Halu Oleo University \\ Email: arisihad14@gmail.com \\ Kamaluddin \\ Halu Oleo University \\ Siam \\ Halu Oleo University
}

\begin{abstract}
This research was accomplished to find out whether Bahasa Inggris textbook for Grade X fulfilled each criterion of textbook evaluation criteria based on Jahangard's theory. The researcher used the qualitative analysis design. The data source was collected from Bahasa Inggris textbook for Grade X published by Pusat Kurikulum dan Perbukuan, Balitbang, Kemendikbud. The instrument of this study was a table of textbook evaluation criteria. The researcher collected the data by using checklist to evaluate the textbook and analyze the data shown by the checklist and make some interpretations, and finally describing the results from the assessment table. The result confirmed that only five of fourteen sub-criteria which did not be fulfilled, they are vocabulary section consists of list of words and their definition, each chapter should consist of four skills, there is a grammar presentation in each chapter and the words are correctly spelled. While the rest nine of sub-criteria were fulfilled. It was recommended to the teacher to be more critical and could cover the weaknesses of the textbook by various teaching style or find another reference outside the textbook.
\end{abstract}

Keywords: Textbook, evaluation criteria.

\section{Introduction}

It is unavoidable that a textbook plays an important role in educational system in Indonesia. According to Razmjoo (2007), textbooks play a crucial role in language contexts all over the world. In particular conditions, textbook could be a main tool for 
students to get information. In another condition, textbook could be an additional lesson for students.

When a new curriculum is implemented, all new textbooks are published as well. As their responsibility, the government, in this case, is the Ministry of Education and Culture had made some laws in the form of regulations for designing and arranging textbooks. Some publishers then claim their textbooks as the most appropriate textbook to be used in teaching learning process. Some cases of inappropriate of textbook exist in Indonesia, such as the case of Yudhistira publisher which shows inappropriate picture in their textbook. This problem happened since the government did not check the appropriateness of all textbooks accurately. To deal with this case, the government never gives up to create textbooks for students which suit with the current curriculum outside the private publishers.

In responding this problem, some experts such as Cunningsworth (1995), Chastain (1971), Tucker (1975), Cowles (1976), Daoud and Celce-Murcia (1976), Candlin and Breen (1979), River (1981), Williams (1983), Sheldon (1988), Skierso (1991), and Ur (1996) proposed a textbook evaluation criteria to check whether a textbook is categorized as a good textbook or not. Textbook evaluation is an important process which can be beneficial to publishers, teachers and also students. Amrani (2011) said that publishers have always needed to evaluate their materials in order to satisfy a wide range of end users. Except for publishers, teachers also need to evaluate teaching materials for a variety of reasons. Evaluation helps the selection of an appropriate textbook.

Some previous researchers had analyzed some textbooks which were published by private publishers such as "Pathway to English" textbook published by Erlangga and "Let's Talk" published by Pakar Raya and both of them were considered as a fair textbook.

Based on the above reasons, the researcher wondered to know whether the textbook which was published by the Ministry of Education and Culture had fulfilled the criteria based on the Jahangard's theory. The researcher had analyzed the English 
textbook for Grade X published by Pusat Kurikulum dan Perbukuan, Balitbang, Kemendikbud. This textbook is its third edition. The first edition was published in 2014. The second edition was published in 2016, and the third edition was published in 2017. This book will always be modified since there are some suggestions from teachers or readers of the textbook. This textbook was specifically arranged to implement the curriculum of 2013 and used in most of senior high school in Indonesia. There are some reasons which influence the big number of user of this textbook. The first, this book is free downloaded. Even if this book is sold, the government had limited the price in range Rp.16.000 - Rp.24.000, depends on particular zones. The second, this book is considered has fulfilled the criterion of a good textbook and met the current curriculum demand.

Based on the background of this study, the research question is "Does Bahasa Inggris textbook for Grade $\mathrm{X}$ fulfill each sub-criterion of the textbook evaluation criteria?"

\section{Literature Review}

\section{Definition of Textbook}

Nowadays, textbook is a main device to deliver material to students. The using of the textbook in the classroom can help the teachers to provide the materials. The students can use the textbook to practice their understanding about the materials given by the teacher. According to Tomlinson (2005), a textbook provides the core materials for a course. Language textbooks cover grammar, vocabulary, pronunciation, functions, and the skills of reading, writing, listening and speaking are included in a textbook for language teaching.

There are several functions of textbooks in language programs. Richards (2001: 254 cited in Semitha), mentions some functions of textbooks, they are:

a. A reading textbook might be the basis for a course on reading skills, providing both a set of reading texts and exercises for skills practice. 
b. A writing textbook might provide model compositions and a list of topics for students to write about.

c. A speaking textbook might provide passages for students to read and discuss.

d. A listening textbook together with audiocassettes or CDs might serve as the primary listening input in a listening course.

e. A grammar textbook might serve as a reference book and provide examples as well as exercises to develop grammatical knowledge

\section{The Criteria of Textbook Evaluation by Jahangard}

Jahangard (2007) has evaluated the checklist criteria based on ten experts. They are, Chastain (1971), Tucker (1975), Cowles (1976), Daoud and Celce-Murcia (1976), Candlin and Breen (1979), River (1981), Williams (1983), Sheldon (1988),

Skierso (1991), and Ur (1996). He developed the criteria of textbook evaluation by comparing standard from 10 different sources then compiling those criteria into thirteen criteria to evaluate the textbook.

The first criterion is whether the objectives explicitly laid out in an introduction and implemented in the material. It means that there is an introduction that attempts to clarify the intended teaching objectives. A good textbook needs to state the goals which the teachers and the learners should achieve. The ultimate goals of the curriculum are clarified. The authors of the book clearly specify the final objectives of the curriculum in vivid words so that the stakeholders know what they are expected to have learnt at the end of the program (long term objectives). Likewise, the short term objectives remain specified in the introduction. So the teachers know what the learners should be able to do to demonstrate that they have achieved the intended objectives at the end of each course e.g. at the end of each year in the educational program.

The second criterion is whether a textbook contains good vocabulary explanation and practice. It means that a textbook should concern with the correspondence between the different senses of the word introduced in the new words sections and the senses which are used in the reading comprehension. It is needed to 
show the fact obviously that a word might have several different senses.

The third criterion is whether it approaches educationally and socially acceptable to target community. A good textbook should include all five aspects: structure, function, situation, topic, and skills which are reasonable, good enough so that can be logically acceptable in relating to a certain community.

The fourth criterion is whether it has a periodic review and test sections. At the beginning and the end, review exercises are attached sometimes. However, they are not enough. It seems better to include tests and review tests at the end of each one of the lessons. It is worth mentioning that the tests should be comparable and compatible with the format and the testing methods which will be employed in the mid- term and final exams.

The fifth criterion is whether the textbook has a clear attractive layout and print easy to read. The textbooks are acceptable regarding the clarity and orthographic beauty. However, it would be more appealing if colorful pictures of real people and real environment were used. Both teachers and students will be more interested in using the book compared to the textbooks which are not.

The sixth criterion is whether it contains appropriate visual materials. Visual materials can be defined as the facilities that can be employed by teachers and learners to enhance language learning in classrooms. They may range from simple hand-made real, charts and pictures to electronic and digital materials. Providing appropriate visual materials means giving information clearly furnished with illustrations that facilitate students in understanding each material. Whether it is in reading comprehension or grammar section.

The seventh criterion is whether it has interesting topics and tasks. The topics of reading vary from factual to anecdotal ones and sometimes are funny stories. It is difficult to judge on behalf of the learners whether those are interesting for them or not. It seems that it would be better if the topics are updated to become more congruent with the taste of the new generation which might be a bit different from that of the authors who designed the books at least ten years ago. Tasks that are very 
traditional would make students more easily saturated. A good textbook should carry out that problem well.

The eight criterion is whether the textbook contains clear instructions. Most of the instructions should be clear and easy to be understood. Even if the learners might not be familiar with the structures and the lexis used in the instructions, the models given for each group of exercises provide contextual clues for the learners as to what they are expected to do. The bias instructions will create bias answers and learning process.

The ninth criterion is whether the content is clearly organized and graded. Sentences will be too complex for learners to understand. It may happen because they do not know the meaning of the new words included in. Planning the content carefully and consisting in series for each material to be slightly more difficult can help students achieve each competency without feeling tired and stressed.

The tenth criterion is whether it contains plenty of authentic language. Authenticity is defined by Johnson and Johnson (1999) as follows: Texts are said to be authentic if they are genuine instances of language use as opposed to exemplars devised specially for language teaching purposes. It means that the content of a textbook should have examples based on facts. The contextual illustrations can help the learners easily create an imagination on their mind.

The eleventh criterion is whether it contains good grammar presentation and practice. Grammar drills occupy the lion's share of each lesson and range from repetition, substitution to transformational ones. They are aimed at providing the learners with oral practice of the intended grammatical points.

The twelfth criterion is whether it contains fluency practice in all four skills. Fluency means a smooth way of moving. Practice means the actual performance of an activity. In sum, the criteria above indicate that there is no separation between the activities to the other activities. The four skills tested in nature so that students gain experience while studying in the four skills.

The thirteenth criterion is whether it encourages learners to develop own 
learning strategies and to become independent in their learning. A scientist states that "good reader usually browses the whole text before starting to read and pays attention

to the organization and structure of the text as well as other parts which are relevant and compatible to the goals of the reading. The explanation above simply is an illustration that successful learners are persons who are able to develop his knowledge after completing the learning process by using a textbook."

\section{Methods}

This research used a descriptive qualitative design. This study had analyzed an English textbook entitled Bahasa Inggris for SMA/MA Grade X published by Pusat Kurikulum dan Perbukuan, Balitbang, Kemendikbud. This research used human as the main instrument in this case is the researcher himself, and the table of textbook evaluation criteria proposed by Jahangard.

The procedure of analyzing the data was done as follows: the first step, the researcher chose the book which would be analyzed; the second step, the researcher analyzed the textbook by looking at the fulfillment of criteria; and the last step, the researcher reported the result in the form of writing. In this research, the researcher used documentation and observation techniques.

\section{Findings and Discussion}

The findings are presented and disscussed systematically based on the sequence of criteria in evaluating of a textbook as the following.

1. Objectives are explicitly laid out in an introduction, and implemented in the material

The first sub-criterion is fulfilled because each chapter in this book contained an objective in the opening chapter. The first sub-criterion consists of two parts. First, whether the textbook has objectives in each chapter. Second, whether the objectives are given in the beginning of the book. The first part is fulfilled where there are fifteen objectives from fifteen chapters which means that every single chapter has 
objectives section in the beginning of the chapter.

The second sub-criterion is whether the objectives are suitable with the official syllabus and this criterion is fulfilled. To analyze this sub-criterion, the researcher looked at the content mapping which was attached in the beginning of the textbook and made a table of comparison between basic competences of each chapter and the objectives which should be fulfilled

The third sub-criterion is whether the topics or materials are suitable with the objectives and it is fulfilled. To answer this question, the researcher made a list of topics for each chapter with the objectives and all is revealed that the topic was suitable with the objectives.

\section{Good Vocabulary Explanation and Practice}

First sub-criterion which should be fulfilled is whether there is a vocabulary section in each chapter. Based on the researcher observation, all the chapters in the textbook have a vocabulary section. In this textbook, it is named "Vocabulary Builder".

The second sub-criterion which should be fulfilled is whether "vocabulary section consists of lists of words and their definitions based on the context used". Subcriterion is not fulfilled because there is no single list of vocabulary with their definition available in this textbook. Prince (1996) states that only knowing the translations of the words does not guarantee that they will be successfully to use the word in the context. It means that the existing of this sub-criterion is simply urgent, because knowing a word means knowing more than just its translated meaning.

The third sub-criterion of this criterion is whether each chapter has vocabulary practice. This aspect was fulfilled. There is only one type of vocabulary exercise in this section. The student is asked to complete the sentences by using the list of vocabularies. This sub-criterion is also useful to make the students more critical in analyzing the use of vocabularies in context. 


\section{Fluency Practice in All Four Skills}

The first sub-criterion is whether each chapter consists of four skills. This sub-criterion is not fulfilled because only two chapters which consist of four skills, they are chapter nine and chapter six. Only nine chapters which consist of three skills such as reading, writing, and speaking. Chapter nine, chapter one, and chapter three simply consist of two chapters such as speaking and writing. The last, simply chapter fifteen which consists three skills, such as listening, speaking and writing. The book mostly concentrates to reading, writing, and speaking and seems ignoring listening section.

The second sub-criterion is whether each skill in each chapter is completed with fluency practices. This sub-criterion is fulfilled because each section of skills is completed with fluency practices. There are a lot of fun things to do to develop the student's ability in speaking inside the textbook. For example in chapter one and two, the students are asked to play rock, paper, and scissor. The winner will choose a situation and his partner makes an expression based on the topic, such as the expressions of congratulation.

\section{Good Grammar Presentation and Practice}

The first sub-criterion is whether there is a grammar presentation in each chapter, this sub-criterion is not fulfilled. In this textbook, grammar presentation is called as "grammar review". After doing an observation, the researcher found that there is no grammar review in two chapters, they are chapter II and chapter XV.

The second sub-criterion is whether there are grammar practices in each chapter. This textbook is organized well, every single part of this book should follow the head. It means that, if one chapter does not have a grammar presentation in this case is "grammar review". It means that there is no grammar practice. Evaluation of grammar is always done after grammar presentation.

\section{Appropriate Visual Materials are Available}

There is only one sub-criterion in this criteria, whether there are visual materials available from the book, such as charts, pictures, movies, etc. which are 
relevant with the topics. This aspect is fulfilled. This textbook is supported with relevant visual materials. It is provided in all the chapters in this textbook. Chapter eight entitled "BJ. Habibie" is so relevant with its picture. The picture completes the text about the description of BJ. Habibie. It attaches the picture of BJ. Habibie and on the next, the description are presented. This is very helpful to be comprehended by the students what BJ Habibie looks like. It will not happen if the description is only given without providing the concrete visual materials.

\section{Clear Instructions}

There is only one sub-criterion in this criterion, whether the instructions of the exercises or practices are clear and easy to understand, in terms of completed by examples and/or given in the learners' native language. This aspect is fulfilled since there are hundreds of instructions in this textbook and the researcher perceived that most of the instructions are clear and easy to understand. Below are some examples of instructions in Chapter I of the textbook.

Match the words with their Indonesian equivalents. Compare your work with your classmates. The first one has been done for you.

Listen to your teacher reading aloud these words. Repeat after him/her.

Read the text carefully. Your teacher will identify you as A or B. Students identified as A, read Text 1; students identified as B, read Text 2.

\section{Clear Attractive Layout and Print Easy to Read}

The first sub-criterion is whether the words in textbook are correctly spelled and clearly printed. This sub-criterion is not fulfilled, because there are some errors of spelling found in the textbook. The researcher had found 10 errors in spelling, they are:

1. "Identify the structure of the organisation of the letter". (p. 10)

2. "E. Mixed (Pronouns and Possesive Adjectives) (p.15)

3. “...members are given the priviledge to discover the thundering ..." (p.73) 
4. “...it is advised to reoster as soon as possible..." (p.92)

5. "Habibie's father dieds" (p.138)

6. “Are your classmate's sentences gramaticaly correct?

7. "...How will you express your thanksfullness" (p.148)

8. "...her efforts in fighting against the Dutch colonialization" (p.148)

9. “...Malin Kundang was a healthy, dilligent, and strong boy...” (p. 172)

10. “Coem running" (p. 205)

According to Nick Stockton (2014), when we look what we have written, we approach the piece with a version of what we would like to see already in our minds. So even if a critical chunk of information is missing, we do not notice because the explanation is still alive in our minds. The researcher considered that this theory is available to spelling error number $1,2,3,4,6,7,9$, and 10. Those kinds of error could be said as human error, because there are only one or two missing or over letter in the spelling error. This is a normal condition, where the writers had to type 233 pages. So, the correct spellings for those words are, organization, possessive, privilege, register, grammatically, thankfulness, diligent and come.

A different problem happened in spelling error number five and ten. There is a grammar mistake in number five, where "Habibie's father dieds" is an action which happened in the past. The verb used in the sentence must be verb II, without "s". Number ten was serious problem, where the author wrote "colonialization". The word "colonialization" is not exist either in English dictionary or Bahasa Indonesia. This word is freely translated from non-standard word regarding affixation in Bahasa Indonesia into English. The correct word must be "colonization".

The second sub-criterion is whether this textbook consists of colorful pictures of real people and real environment. This aspect is fulfilled which means that it is acceptable regarding the clarity and orthographic beauty. This book consists of colorful picture and real picture in some chapters such as chapter III. Although theare first graders of senior high school level. The presence of real picture and animation will help the students for being relax and attracted. 


\section{Conclusion and Recommendation}

The result confirmed that only five of fourteen sub-criteria which did not be fulfilled, they are vocabulary section consists of list of words and their definition, each chapter should consist of four skills, there is a grammar presentation in each chapter and the words are correctly spelled. While the rest nine sub-criteria were fulfilled. It was recommended to the teacher to be more critical and could cover the weaknesses of the book by various teaching style or find another reference outside the analized textbook.

\section{References}

Amrani, F. (2011). The process of evaluation: a publisheres view. In Tomlinson, B. (Ed.), Materials development in language teaching. Cambridge: Cambridge University Press, 267-295.

Arikunto, S. (2006). Prosedur Penelitian: Suatu pendekatan Praktik. Jakarta: Rineka Cipta

Ary, Donald and Jacobs, C., Lucia, and Razavich, Ashgar. 1979. Introduction to Research in Education. New York: Holt, Rinehart and Wiston

Brown, H. D. (2007). Principles of Language Learning and Teaching. London, Pearson Longman.

Cresswell, J. (2007). Qualitative Inquiry \& Research Design: Choosing Among Five Approaches, $2^{\text {nd }}$ ed. California: Sage Publication.

Cunningsworth, A. (1995). Choosing your Coursebook. Cambridge, Cambridge University Press.

Ellis, R., Helgesen, M., Browne, C., Gorsuch, G., Schwab, J. 1996. High Impact Coursebook. Longman.

Gall, J. P. (2007). Educational Research: An Introduction. late of Utah State University Pearson.

Graves, M.F. (2000). A vocabulary program to complement and bolster a middlegrade comprehension program. In B.M. Taylor, M.F. Graves, and P. Van Den

Broek (eds.), Reading for meaning: Fostering comprehension in the middle grades. New York: Teachers College Press

Harmer, Jeremy. 1991. The Practice of English Language Teaching. New York: Longman

Hill, David A. Visual Impact: Creative language learning through pictures. Essex: Longman Group UK Limited, 1990. ISBN 0-582-03765-4 
https://mic.com/articles/96282/the-scientific-reason-making-typos-doesn-t-mean-youre-careless\#.eQYkDP7fR accesed on 30 April 2018

Hutchinson, Tom \& Eunice Torres. (1994). The Textbook as agent of change. English Language Teaching Journal, 48.

Jack C. Richards, T. S. R. (2001). Approaches and Methods in Language Teaching. Cambridge, Cambridge University Press.

Jahangard (2007). "The Asian EFL Journal Quarterly." Asian EFL Journal9(2): 133.

Jordan, R. R. (1997). English for Academic Purposes Cambridge Cambridge University Press.

McGrath, I. (2002). Materials Evaluation and Design for Language Teaching. Edinburgh, Edinburgh University Press.

Razmjoo, S.A. (2007). High schools or private institutes textbooks? Which fulfill communicative language teaching principles in the Iranian context? Asian EFL Journal 9(4), 126-140.

Shumin, K. (2002). Factors to consider: Developing adult EFL students' speaking abilities. J. C. Richards, \& W. A. Renandya (Eds.), Methodology in Language Teaching. Cambridge: Cambridge University Press

Skierso, A. 1991. "Textbook selection and adaptation." In Celce-Murcia, M. (ed.) Teaching English as a Second or Foreign Langauge. Newbury House.

Tomlinson, B. (2005). Developing materials for language teaching. London, UK: Continuum. 
